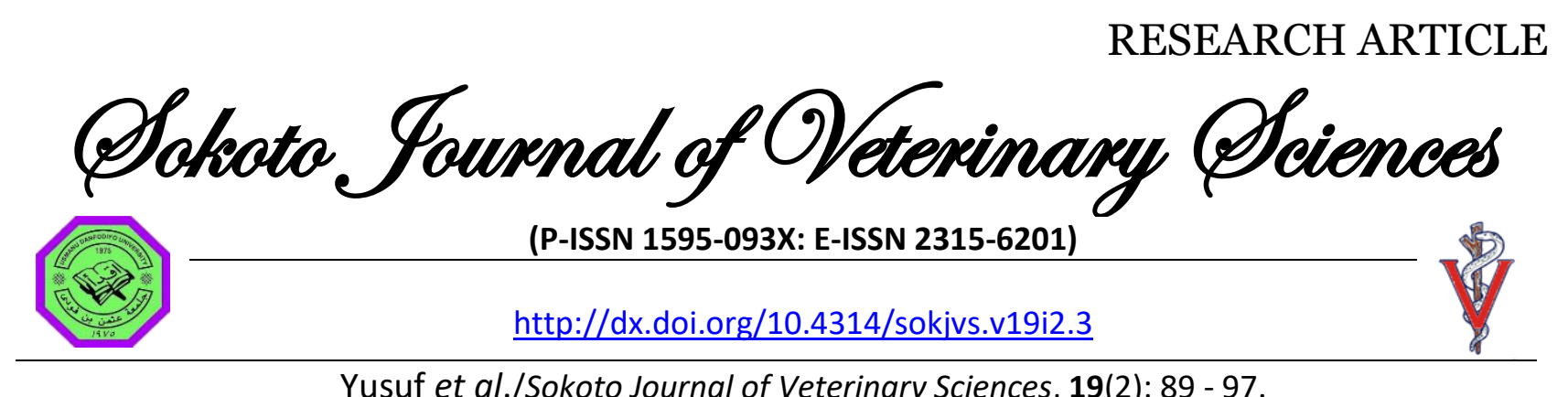

\title{
Antimicrobial-resistant in Escherichia coli isolated from different effluent locations within Ahmadu Bello University, Zaria, Nigeria
}

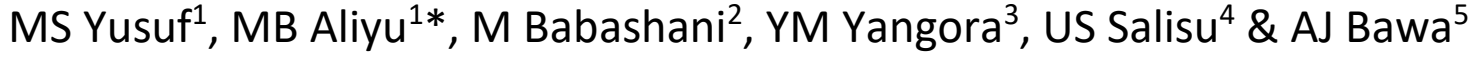 \\ 1. Department of Veterinary Public Health and Preventive Medicine, Faculty of Veterinary Medicine, Ahmadu \\ Bello University, Zaria, Nigeria \\ 2. Veterinary Teaching Hospital, Faculty of Veterinary Medicine, Ahmadu Bello University, Zaria, Nigeria \\ 3. Department of Forestry, Audu Bako College of Agriculture, Danbatta, Kano State, Nigeria \\ 4. Department of Animal Science, Faculty of Agriculture, Federal University Dutsin Ma, Dutsin Ma, Katsina \\ State, Nigeria \\ 5. Kano State Ministry of Agriculture and Natural Resources, Kano, Nigeria
}

*Correspondence: Tel.: +2348154813755; E-mail: mbaliyu@abu.edu.ng

\begin{abstract}
Copyright: (c) 2021
Yusuf et al. This is an

open-access article published under the terms of the Creative Commons Attribution License which permits unrestricted use, distribution, and reproduction in any medium, provided the original author and source are credited.
\end{abstract}

Publication History: Received: 10-11-2020 Revised: 26-02-2021 Accepted: 04-03-2021

\section{Abstract}

The safety of municipal water is increasingly becoming of concern globally. Agricultural activities, industrial and residential effluents and community waste are ways through which water sources are contaminated and resistant bacteria can be spread via effluents to municipal water. The study aimed to isolate and determine the distribution of antimicrobial drug-resistant Escherichia coli from different points of the University sewer system in April 2018. A total of 48 samples were collected twice weekly from the six randomly selected inspection chamber sites out of the 14 identified sites. The selected sites of the sewer were located in some hostels, markets and health service areas within the ABU. main campus. The samples were processed by culturing on an EMB agar plate followed by biochemical characterization using conventional biochemical tests and Microbact 12E. An antimicrobial sensitivity test was also carried out using 13 different antibiotic discs. The results obtained revealed that the Community market had an isolation rate of $4(50 \%)$, while Sickbay had $3(37.5 \%)$ and Danfodiyo hostel with 2(25\%). Multiple antimicrobial resistance index (MARI) was found to be 0.31 from four isolates (36\%) of E. coli of which $3(75 \%)$ were sampled from Sickbay and $1(25 \%)$ from ABU Dam. Also, five isolates (45\%) had MARI of 0.23 , of which $2(40 \%)$ were sampled from Danfodiyo hostel, $1(20 \%)$ from Ribadu hostel and 2(40\%) from Community market. The $E$. coli isolates were more resistant to Ampicillin, tetracycline and cephalothin. Other bacteria isolated were Klebsiella ozaenae, Hapnea alvei and Morganella morganii all with MARI of 0.31 . There is a need for public health awareness on the effect of discharging antibiotic-resistant $E$. coli contaminated effluent into the environment and water bodies. Hence, the public health significance of recycling such water for domestic usage and agricultural purpose.

Keywords: Antimicrobial-resistant, ABU Zaria, Effluents, E. coli, Sewer 


\section{Introduction}

Effluent is a treated or untreated wastewater/sewage that flows out of a treatment plant, sewer, or industrial outfall and is discharged into surface waters (USEPA, 2006).

Urban effluent comprises mainly of water (99.9\%) with relatively small concentrations of suspended and dissolved organic and inorganic solids. Substances present in effluents include fats, carbohydrates, lignin, soaps, synthetic detergents, proteins and their decomposition products, etc. Inorganic substances from domestic and industrial sources are also present in municipal effluents (Tilley et al., 2014).

In agricultural use of effluents, the contaminants of great public and environmental health concern are the pathogenic micro- and macro-organisms. These pathogens include viruses, bacteria, protozoa and helminths, which are found in different concentrations and will survive in the environment for long periods (WHO, 2006). Pathogenic bacteria are usually present in wastewater at much lower levels than the $E$. coli form group of bacteria, which are much easier to identify and enumerate. Escherichia coli are the most widely adopted indicator of faecal pollution and they can also be isolated and identified (Fricker, 2000).

Escherichia coli (E. coli) is a Gram-negative, facultative anaerobic, rod-shaped, coliform bacterium of the genus Escherichia that is commonly found in the lower intestine of warm-blooded organisms (endotherms) (Tenaillon et al., 2010).

E. coli is a dominant coliform in aquatic environments contaminated by antimicrobialresistant bacteria originating from human and animal faeces. The $E$. coli in such environments are associated with antibiotic resistance genes that can be transferred to human and animal flora, where they can exert intense pressure for the spread of resistance (Adefisoye \& Okoh, 2016).

Antibiotic resistance is the ability of organisms like bacteria and fungi to defeat the drugs designed to inhibit/kill them (CDC, 2010). Pollutants and antibiotic-resistant bacteria are constantly released as effluents into the environment which contribute to significant public health risk (McLellan et al., 2015). A major process of E. coli and other organisms becoming resistant is the selective pressure of antimicrobial use in human and animal medicine, as well as in aquaculture and agriculture (Kummerer, 2009). Wastewater is a hotspot of antibioticresistant gene exchange where environmental bacteria interact with microbes that originated from humans and other animal sources, through horizontal gene transfer (HGT) (Wackett, 2015). Opportunistic pathogens often have large and versatile genomes, prone to sharing genetic materials (Vanderlene et al., 2010). This peculiarity helps these organisms to colonize a more diverse set of environments. As consequence, aquatic ecosystems may become a threat to human health when they are affected by pollutants carrying resistant bacteria (Baquero et al., 2008).

Antibiotic resistance, particularly MAR, is a major public health threat, and the presence of resistant organisms in environmental waters is an emerging concern in the world (Marti et al., 2013). The important role of the environment in the dissemination of antibiotic resistance is acknowledged, and the aquatic environment has been shown to act both as a natural reservoir and a channel for the spread of clinically relevant antibiotic resistance traits (Michael, et al., 2013; Canencia, et al., 2016). The increasing spread of antimicrobialresistant genes among environmental bacteria has led environmental scientist to consider Antimicrobial-resistant bacteria (ARB) and antimicrobial-resistant genes (ARGs) as emerging pollutants or contaminant in the natural environment (Pruden et al., 2013). Wastewater discharges from domestic sources affect the diversity of resistant bacteria (Czekalski et al., 2012). These impacts also shape the genetic pool of water bodies by increasing the abundance of antibiotic resistance genes within the habitats (Tacão et al., 2012). Developing countries like Nigeria have the highest concentrations of antibiotics and resistant bacteria in effluents released from hospitals and drug manufacturing sites (Bréchet et al., 2014). Effluents containing chemicals, antimicrobials and detergents or their residues are capable of exerting selective pressure to the microbial flora in the water and can select for resistant bacteria (Bennett, 2008; Schmitt et al., 2017). The study aimed to isolate and determine the antibiogram of $E$. coli and some Enterobacteriaceae from different effluent points of the university sewer system.

\section{Materials and Methods}

Study area

The study was conducted at Ahmadu Bello University main campus located in Zaria, Kaduna State of Nigeria on latitude $11^{\circ} 03^{\prime} 60.00^{\prime \prime} \mathrm{N}$ longitude $7^{\circ} 41^{\prime} 59.99^{\prime \prime} \mathrm{E}$, at an altitude of $550-700$ meters. It is 
about $13 \mathrm{~km}$ from Zaria-city on the Sokoto road, $8 \mathrm{~km}$ to Shika and $7 \mathrm{~km}$ from Bassawa. The University covers a land area of about 7,000 hectares and comprises 17 Faculties, 106 Academic Departments, a Postgraduate School and a Distance Learning Centre. It also has 16 Research Institutes, 7 Centres of Excellence, a Microfinance Bank, Mini Refinery, University Health Service, Teaching Hospital, a School of Basic and Remedial Studies, a Demonstration Secondary School, a Primary School, 5 Guest houses, 3 Hotels and a Consultancy Outfit which provides a variety of services to the University and the wider society. It has a population of over 45,000 students and over 10,000 Academic and support staff.

The existing sanitary sewerage system (ESSS) at ABU Zaria is used for the conveyance and treatment of sewage (domestic wastewater) for the University's academic area. In the year 1962, it uses a trickling filter to treat the sewage from some of the students' hostels, kitchen, and academic blocks. Over time, with an increase in the campus population, some of the halls of residence, their kitchen wastes were drained to an open ditch while the other buildings had separate and individual septic tanks to treat their wastewater. In 1972, a new "exigest plant model R" was installed and activated. Due to high load, in 1979 a waste stabilization pond (WSP) was designed and constructed as the first of its kind to be implemented in Nigeria. The ESSS is functional but evaluated to be $38 \%$ efficient, major challenges are poor maintenance of broken sewer pipes and low network coverage (Otun et al., 2009).

\section{Study design}

A cross-sectional study was conducted to sample three (Hostels, Markets and University Health Services) of the six (Hostels, University Health Services, Markets, Faculties/Departments, Residential Quarters and ABU Dam) major contributors of the $A B U$ sewage network based on accessibility to inspection chambers.

The sampling sites identified were Undergraduate hostels (Suleiman, Danfodiyo, ICSA/Ramat, Ribadu, Amina), Postgraduate hostels (Sasakawa, Akenzua, Suleiman, Amina), Markets (community market, social centre, ICSA/Ramat), University Health Service (Sickbay) and ABU Dam. Six sites were selected from the fourteen identified sites by simple random sampling method (Horvitz \& Thompson, 1952).

A total of 48 wastewater samples were collected at the inspection chambers of the six randomly selected locations, twice weekly for four weeks in April 2018. The collection was done every Monday and Wednesday which were the routine inspection days for the maintenance staff from the University Health Services, to have access to the inspection chambers. $10 \mathrm{mls}$ of the wastewater were collected at all the locations using a sterile syringe and deposited in sterile test tubes which were covered neatly and transported to the bacterial zoonoses laboratory of the Department of Veterinary Public Health and Preventive Medicine ABU Zaria.

Each sample was processed by making a 100-fold serial dilution, from which $1 \mathrm{ml}$ was taken and added to $9 \mathrm{ml}$ of Tryptone soya broth as enrichment and incubated for 24 hours. This was then plated on a selective media (EMB) and incubated for $24 \mathrm{hr}$ as first described by Levine (1918).

\section{Biochemical test}

Colonies growing on nutrient agar slants were subjected to further biochemical tests namely; Simmon citrate, Urea, Triple Iron Sugar (TSI), Sulfate, Indole, Motility (SIM) and Methyl Red (MR), Vogesproskeur (VP). Various reactions of the tests such as colour change, motility and gas formation were used to interpret results as either positive or negative after 24-hour incubation. These tests were carried out as described by Khandaghi et al., 2010.

Positive isolates were further characterized biochemically using Microbact 12E (MB1130A+, Oxoid, UK) according to the manufacturer's instruction for further confirmation of $E$. coli due to its higher degree of accuracy in comparison to conventional biochemical tests (Mugg \& Hill, 1981). It uses 4 digit codes that were obtained from the culture and was fed into the computer identification software; which gave the probable identity of the organism tested in percentage score. The Microbact software recommends a $75 \%$ cut-off point for probable identification. All tests that gave less than $75 \%$ were not accepted as $E$. coli.

Antibiotic susceptibility test

Antibiotic susceptibility tests were performed on all the isolates to determine their antibiotic-resistant profiles using the disc diffusion method developed by Kirby - Bauer and standardized by the World Health Organization as modified by Sozmen et al. (2011). Commercially available antimicrobial disks from Oxoid, the UK used were; nitrofurantoin (F300ug), gentamicin (CN10ug), trimethoprim (W5ug), ampicillin (AMP10ug), amoxicillin/clavulanic acid (AMC30ug), chloramphenicol (C30ug), cephalothin (KF30ug), ciprofloxacin (CIP5ug), tetracycline (TE30ug), cefoxitin (FOX30ug), nalidixic 
acid (NA30ug), sulphamethoxazole/trimethoprim (SXT25ug) and Amikacin (AK30ug).

The bacteria were inoculated on tryptone soy broth and incubated at $37^{\circ} \mathrm{C}$ for $24 \mathrm{hrs}$. The turbidity was adjusted to 0.5 McFarland standards (Eduardo et al., 2018) and a sterile swab stick was eluted into the overnight culture broth and any excess moisture were expressed by pressing the swab against the side of the tube. The surfaces of the Mueller Hinton agar was also swabbed completely and then turned at $90^{\circ}$ and repeat the swabbing process until the entire circumference of the plate was covered. The media was allowed to dry for about $5 \mathrm{~min}$ before placing antibiotic discs using an antibiotic dispenser. Then each disc was lightly touched with a sterile inoculating loop to make sure it is in good contact with the agar surface, and then incubated upside down at $37^{\circ} \mathrm{C}$ overnight.

A transparent plastic metric ruler was used across the zone of inhibition (ZI), at the widest diameter to measure from edges of the zones in millimetres. Results were reported for resistance only (CLSI, 2014). Multiple antimicrobial resistance indexes were determined by dividing number of antimicrobials to which the organism was resistant by the total number of antimicrobials to which the organism was exposed.

\section{Results}

Distribution of E. coli based on sample locations

From a total of 48 samples collected from 6 locations, 32 samples were positive for $E$. coli on EMB (Figure1). The positive samples from EMB were subjected to Biochemical tests, 22 were positive. From the 22 biochemical positive samples (Figure 2), 11 were positive on microbat. Samples from the community market had the highest isolation rate $50 \%(4 / 8)$, followed by samples from sickbay with an isolation rate of $37.5 \%(3 / 8)$. Ribadu hostel and $A B U$. Dam had an isolation rate of $12.5 \%(1 / 8)$, while Danfodiyo hostels had an isolation rate $25 \%(2 / 8)$ (Table 1).

\section{Susceptibility of E. coli isolates to antimicrobials} The eleven isolated $E$. coli were subjected to in-vitro activities of 13 antimicrobials (Table 2). Four isolates had the highest multiple antimicrobial resistance index (MARI) of 0.31, while 5 isolates had MARI of 0.23 . Only isolates 1 and 2 were resistant against Trimethoprim (W5) and Sulphamethoxazole/Trimethoprim (SXT25) (Figure3).

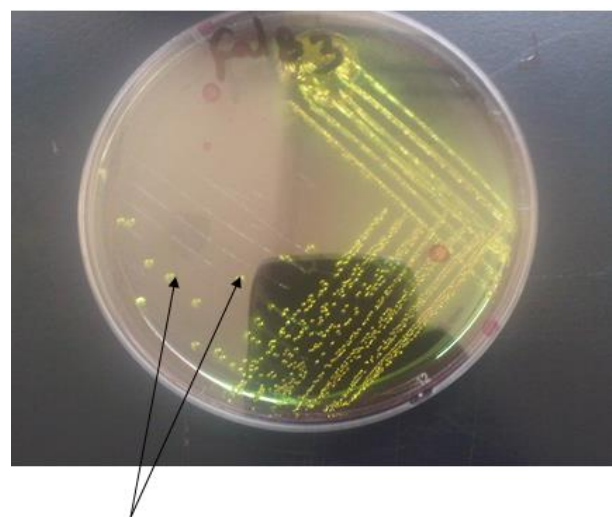

Figure 1: $E$. coli colony growth with greenish metallic sheen on EMB

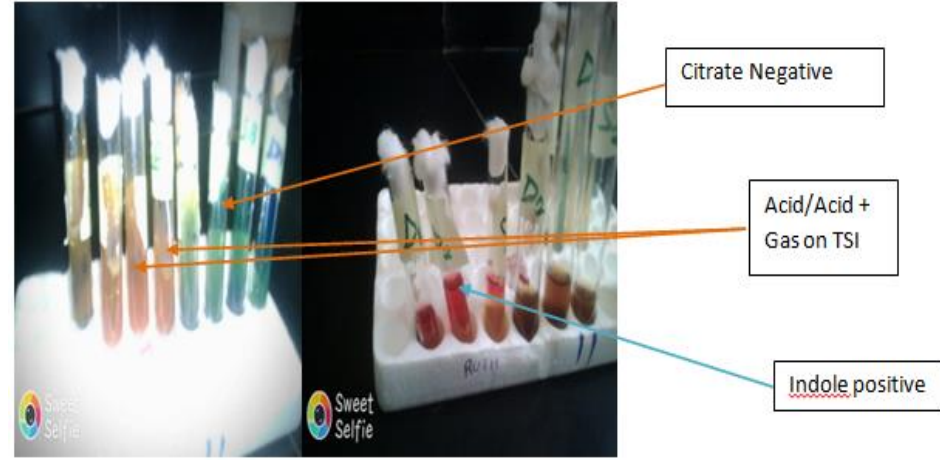

Figure 2: Some biochemical test result from colonies with greenish metallic sheen on EMB

Table 1: Distribution of $E$. coli from effluent samples within Ahmadu Bello University, Samaru, Nigeria

\begin{tabular}{|c|c|c|c|c|c|}
\hline Location & $\begin{array}{c}\text { No. of } \\
\text { samples }\end{array}$ & $\begin{array}{l}\text { No. positive } \\
\text { on EMB }\end{array}$ & $\begin{array}{l}\text { No. positive } \\
\text { biochemical }\end{array}$ & $\begin{array}{l}\text { No. positive on } \\
\text { Microbact }\end{array}$ & $\begin{array}{l}\text { Isolation } \\
\text { rate (\%) }\end{array}$ \\
\hline Danfodiyo hostel & 8 & 4 & 3 & 2 & 25.0 \\
\hline Ribadu hostel & 8 & 6 & 3 & 1 & 12.5 \\
\hline Sasakawa hostel & 8 & 4 & 3 & 0 & 0.0 \\
\hline Community market & 8 & 7 & 6 & 4 & 50.0 \\
\hline Sickbay & 8 & 7 & 4 & 3 & 37.5 \\
\hline ABU dam & 8 & 4 & 3 & 1 & 12.5 \\
\hline Total & 48 & 32 & 22 & 11 & 100.0 \\
\hline
\end{tabular}


Table 2: Multiple antimicrobial resistance (MAR) from isolated E. coli within Ahmadu Bello University, Samaru, Nigeria

\begin{tabular}{lll}
\hline Isolate & Resistance Profile & MAR \\
\hline 1 & W5, AMP10, KF30, SXT25 & 0.31 \\
2 & W5,AMP10, KF30, SXT25 & 0.31 \\
3 & AMP, AMC & 0.2 \\
4 & AMP10, C30, TE30 & 0.23 \\
5 & AMP, TE30 & 0.2 \\
6 & AMP, TE30, AK30 & 0.23 \\
7 & AMP, TE30, AK30 & 0.23 \\
8 & AMP, TE30, NA, AK30 & 0.31 \\
9 & CN10, KF30, CIP5 & 0.23 \\
10 & C30, KF30, CIP5, FOX30 & 0.31 \\
11 & AMP, AMC, TE & 0.23 \\
\hline
\end{tabular}

Note: Nitrofurantoin (F300), Gentamicin (CN10), Trimethoprim (W5), Ampicillin (AMP10), Amoxicillin/Clavulanic acid (AMC30), Chloramphenicol (C30), Cephalothin (KF30), Ciprofloxacin (CIP5), Tetracycline (TE30), Cefoxitin (FOX30), Nalidixic acid (NA30), Sulphamethoxazole/Trimethoprim (SXT25) and Amikacin (AK30)

Table 3: Other Microbes isolated from samples within Ahmadu Bello University, Samaru, Nigeria

\begin{tabular}{lll}
\hline S/N & Sample ID & Isolate \\
\hline 1 & D1 & Klebsiella ozaenae \\
2 & D2 & Hapnea alvei \\
3 & S5 & Klebsiella ozaenae \\
4 & SB & Morganella morganii \\
5 & CM & Morganella morganii \\
\hline
\end{tabular}

D1: Danfodiyo hostel sample 1; D2: Danfodiyo hostel sample 2; CM: Community Market

SB: Sickbay and S5: Suleiman hostel sample 5

Other gram negatives isolated from the effluent samples

Other Gram-negative microbes isolated includes Klebsiella ozaenae (2), Morganella morganii (2) and Hapnea alvei (1) (Table 3).

Susceptibility of other Gram-negatives isolated to antimicrobials

The five isolates were subjected to 13 panels of antimicrobials as shown in Table 4. Three of the isolates were resistant to four antibiotics, while the two remaining isolates were resistant to three antibiotics. The multiple antimicrobial resistance index (MARI) for the two Klebsiella ozaenae (sample D1 and S5) were found to be 0.31 and 0.23 respectively. Hapnea alvei (sample D2) had MARI of 0.31 while that for the two Morganella morganii (sample SB and CM) were 0.23 and 0.31 respectively.

\section{Discussion}

The isolation rate of $E$. coli in the present study was at $23 \%$, which is relatively low when compared to a previous study within Zaria by Chigor et al. (2010) which had $42.1 \%$. This difference may be due to

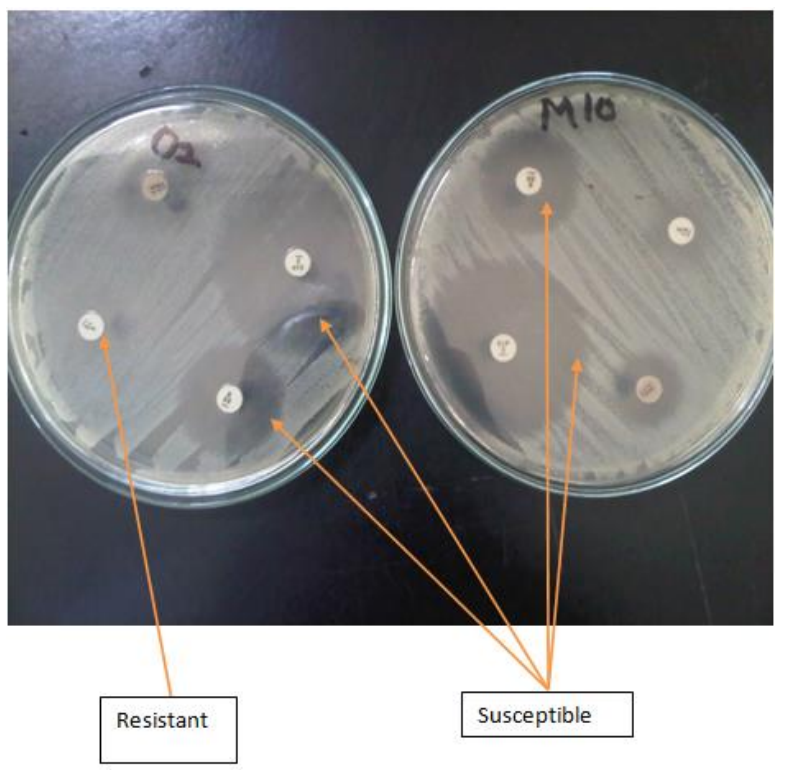

Figure 3: Susceptibility of $E$. coli isolates to certain antimicrobials

variation inlocation and nature of sample. More positives were isolated with conventional biochemical characterization in comparison to positives from Microbact 12E. This may be due to 
Table 4: Multiple antimicrobial resistance (MAR) from isolated microbes within Ahmadu Bello University, Samaru, Nigeria

\begin{tabular}{llc}
\hline Isolate & Resistance Profile & MAR \\
\hline D1 & W5, AMP10, KF30, SXT25 & 0.31 \\
D2 & W5, AMP10, KF30, SXT25 & 0.31 \\
S5 & F300, CN10, AMP10 & 0.23 \\
SB & AMP10, AMC30, TE30, & 0.23 \\
CM & AMP10, KF30, TE30, SXT25 & 0.31 \\
\hline
\end{tabular}

MAR index- Multiple antimicrobial resistance index $=$ No. resistance/Total number of antimicrobials

Microbact $12 \mathrm{E}$ has been more sensitive and specific than conventional biochemical characterization tests (Vithanage et al., 2014). This study reveals Community market had the highest isolation rate (50\%), followed by sickbay and Danfodiyo hostel with $37 \%$ and $25 \%$ respectively. The high rate of isolation at the community market may be due to the wide range of human activities (such as restaurants, vegetables and meat/fish stalls, laundry services, etc.) and the dynamics of the human population. Human activities play a role in the increased spread and contamination of the environment with antibiotic-resistant bacteria and genes (Pruden et al., 2006). Also, animal and human microbiota serve as a reservoir for ARGs. Bacteria passing through the intestinal tract can acquire antibiotic resistance via conjugation and end up in human and animal faeces (Salyers et al., 2004). Another observation was the stagnant nature of the effluent discharge channels, compared to other sample locations. It has been established that stagnant water is a large mixture pool that creates a suitable environment for bacteria and other microorganisms to proliferate (Zlatanović et al., 2017).

The result of the present study indicates resistant $E$. coli in effluents from different locations within the university main campus. ARBs are more resistant to water treatment than their non-resistant counterparts; this prolongs their survival in the environment and spread through recycled water. Antibiotic-resistant virulent $E$. coli strain persisted longer than the less resistant non-virulent $E$. coli strain upon solar radiation, despite both being of the same genus and species (Al Jassim et al., 2017). This calls for a significant public health concern considering they all aggregate at the campus sewage system and the water reused after treatment.

An important finding from the present study was that majority of the $E$. coli isolates had multiple drug resistance (MDR). MDR is the resistance to all the tested antibiotics in at least two of the following 3 classes; Lactams, Aminoglycosides and Quinolones (Doyle et al., 2015). This study shows a majority of the effluent isolates were resistant to Ampicillin followed by Tetracycline and Cephalothin. This pattern was similar to previous studies that show resistance towards $\beta$-lactam, tetracycline, and cephalosporins (Olukosi et al., 2016).

Upon MAR index analysis in the present study, it reveals that $82 \%(9 / 11)$ of the $E$. coli isolates had MARI values greater than 0.2. This finding is similar to that of Chigor et al. (2010), which recorded MARI of $80 \%$ from the aquatic isolates in surface water sources in Zaria. The result is low in comparison to Edward et al. (2020), which recorded 99.8\% E. coli with MARI $>0.2$ from abattoir wastewater in Abia State. A MAR index of 0.2 is used to distinguish between low and high-risk contamination sources (Krumperman, 1983). In Nigeria, poor drug quality is another contributory factor to multiple drug resistance through sub-inhibitory selective pressure. The poor-quality drugs may be due to poor preparation, low or no active content and poor storage (Okeke \& Sosa, 2003). This indicates a possible significant exposure of $E$. coli in the environment to antibiotics, leading to selection pressure. A previous study reveals that multiple drugs resistance in bacteria is associated with plasmids that have several resistance determinants (Baker et al., 2018).

It has been noted that the spread of antibioticresistant bacteria in the environment may result to increase resistance in certain human infectious diseases (Titilawo et al., 2015). The present study also established the occurrence of other Gramnegative isolates from the effluent samples.

The isolates were more resistant to ampicillin, followed by cephalothin and sulphamethoxazole/trimethoprim. The isolates were more resistant to ampicillin, followed by cephalothin and sulphamethoxazole/trimethoprim. Nonpathogenic ARB can serve as a reservoir with the potential to transfer ARGs to non-antibiotic resistant pathogens (Ashbolt et al., 2013), hence contributing to the spread of ARB. Klebsiella spp. is amongst the most common causes of a variety of communityacquired and hospital-acquired infections. Klebsiella 
ozaenae is a subtype of $K$. pneumonia and is known to cause chronic inflammatory disease of the upper respiratory tract (Falkow \& Mekalanos, 1990).

In conclusion, effluents discharged from sickbay, Danfodiyo hostel, Ribadu hostel, Community market and $A B U$ Dam in the campus serves as a shelter for antibiotic-resistant $E$. coli and other enterobacteriaceae as revealed by the study. The MAR index values are of great public health significance, hence the need to regularly evaluate the presence and quantity of $A R B$ in reclaimed water. The contamination of water bodies with such effluents will render them unsafe for irrigation and domestic use. Several studies have established that conventional sewage treatment plants do not entirely remove $A R B$ and ARG from treated effluents. To minimize the potential risk of effluent to public health and the environment, the sewage system should be properly maintained and channelled to a functional facility to ensure wastewater can be safe for recycle and agricultural use.

\section{Conflicts of Interest}

The authors declare no conflict of interest.

\section{References}

Adefisoye MA \& Okoh Al (2016). Identification and antimicrobial resistance prevalence of pathogenic Escherichia coli strains from treated wastewater effluents in Eastern Cape, South Africa. Microbiology Open, 5(1): 143-151.

Ashbolt NJ, Amézquita $A$, Backhaus T, Borriello $P$, Brandt KK, Collignon P \& Topp E (2013). Human health risk assessment (HHRA) for environmental development and transfer of antibiotic resistance. Environmental Health Perspectives, 121(9): 993-1001.

Al-Jassim N, Mantilla-Calderon D, Wang T \& Hong PY (2017). Inactivation and gene expression of a virulent wastewater Escherichia coli strain and the nonvirulent commensal Escherichia coli DSM1103 strain upon solar irradiation. Environmental Science \& Technology, 51(7): 3649- 3659.

Baker S, Thomson N, Weill FX \& Holt KE (2018). Genomic insights into the emergence and spread of antimicrobial-resistant bacterial pathogens. Science, 360(6390): 733-738.

Baquero F, Martínez JL \& Cantón R (2008). Antibiotics and antibiotic resistance in water environments. Current Opinion of Biotechnology, 19(3): 260-265.
Bennett PM (2008). Plasmid encoded antibiotic resistance: Acquisition and transfer of antibiotic resistance genes in bacteria. British Journal of Pharmacology, doi.10.1038/sj.bjp.0707607.

Bréchet C, Plantin J, Sauget M, Thouverez M, Talon D \& Cholley P (2014). Wastewater treatment plants release large amounts of extendedspectrum $\beta$ - lactamase-producing Escherichia coli into the environment. Clinical Infectious Diseases, 58(12): 165865.

Canencia OP, Dalugdug MD, Emano AM, Mendoza R \& Walag AMP (2016). Slaughter waste effluents and river catchment watershed contamination in Cagayan de Oro City, Philippines. Journal of Biodiversity, Conservation and Environmental Sciences, 9(2): 142-148.

Centres for Disease Control and Prevention (CDC) (2010). National Antimicrobial Resistance Monitoring System for Enteric Bacteria. (NARMS): Human isolates, final report, http://www.cdc.go/arm/d/010annual- report- narms.pdf), retrieved 1512-2020.

Chigor VN, Umoh VJ \& Smith SI (2010). Occurrence of Escherichia coli 0157 in a river used for fresh produce irrigation in Nigeria. African Journal of Biotechnology, 9(2): 178-182

CLSI (2014). Clinical and Laboratory Standards Institute. Performance standards for antimicrobial disk and dilution susceptibility tests for bacteria isolated from animals. National Committee for Clinical Laboratory Standards, Wayne, Pennslyvania, Approved Standard M 100-S24 (11).

Czekalski N, Berthold T, Caucci S, Egli A \& Bürgmann $H$ (2012). Increased levels of multiresistant bacteria and resistance genes after wastewater treatment and their dissemination into Lake Geneva, Switzerland. Frontiers in microbiology, 3 (106): 43-48

Doyle ME (2015). Multidrug-resistant pathogens in the food supply. Foodborne Pathogens and Disease, 12(4): 261-279.

Eduardo LG A, Ramirez BS, Maribel CF, Pescador MIGN \& Cruz FJM (2018). Low accuracy of the McFarland method for estimation of bacterial populations. African Journal of Microbiology Research, 12(31), 736-740.

Edward KC, Ibekwe VI, Amadi ES \& Umeh SI. (2020). Prevalence and antibiotic susceptibility 
pattern of Escherichia coli isolated from abattoir wastewaters in Abia State, Nigeria. International Research Journal of Public \& Environmental Health, 7 (5): 140-148.

Falkow JP \& Mekalanos J (1990). The Enteric bacilli and vibrios. In: Microbiology (B Davis, R Dulbecco, $H$ Eisen, $H$ Ginsberg, editors) fourth edition. JB Lippincott, Philadelphia. 576-579.

Falkow S \& Mekalanos J (1990). The enteric bacilli and vibrios. Microbiology, 4: 576-579.

Fricker CR (2000). Water, Air and Soil Pollution, Kluwer Academic Publishers, Netherlands, Vol.123, 35-41.

Horvitz DG \& Thompson DJ (1952). A generalization of sampling without replacement from a finite universe. Journal of the American statistical Association, 47(260): 663-685.

Khandaghi J, Vadood R \& Abolfazi B (2010). Isolation of Escherichia coli 0157:H7 from manure fertilized farms and raw vegetables grown on it, in Tabriz city in Iran. African Journal of Microbiology Research, 4 (9): 891-895.

Krumperman PH (1983). Multiple antibiotic resistance indexing of Escherichia coli to identify high-risk sources of fecal contamination of foods. Applied and Environmental Microbiology, 46(1): 165170.

Kummerer $\mathrm{K}$ (2009). Antibiotics in the aquatic environment - a review -part 1 Chemosphere, 75: 417-434.

Levine M (1918). Differentiation of B. coli and B. aerogenes on a simplified eosin-

methylene blue agar. The Journal of Infectious Diseases, 23(1): 43-47.

Marti E, Jofre J \& Balcazar JL (2013). Prevalence of antibiotic resistance genes and bacterial community composition in a river influenced by a wastewater treatment plant. Plos one, 8(10): e78906.

McLellan SL, Fisher JC \& Newton RJ (2015). The microbiome of urban waters. International Microbiology: The Official Journal of the Spanish Society for Microbiology, 18(3): 141-149.

Michael I, Rizzo L, McArdell CS, Manaia CM, Merlin C, Schwartz T \& Fatta-Kassinos D (2013). Urban wastewater treatment plants as hotspots for the release of antibiotics in the environment: a review. Water Research, 47(3): 957-995.

Mugg P \& Hill A (1981). Comparison of the Microbact-12E and $24 \mathrm{E}$ systems and the
API-20E system for the identification of Enterobacteriaceae. Epidemiology \& Infection, 87(2): 287-297.

Okeke IN \& Sosa A (2003). Antibiotic Resistance in Africa-Discerning the Enemy, Plotting a Defense. Africa Health, 25(3): 10-15

Olukosi OM, Ameh JB, Abdullahi IO \& Whong CMZ (2016). Physicochemical Quality of Drinking Water from Various Water Sources of Kaduna State, Nigeria. Bayero Journal of Pure and Applied Sciences, 9(2): 141 - 144

Otun JA, Lukman S, Ismail A, Adie DB \& Abubakar UA (2009). Evaluation and improvement design of the sanitary sewerage system at Ahmadu Bello University Zaria. Nigeria Journal of Engineering, 16(215): 200-215.

Pruden A, Pei R, Storteboom H \& Carlson KH (2006). Antibiotic resistance genes as emerging contaminants: studies in northern Colorado. Environmental Science \& Technology, 40(23): 7445-7450.

Pruden A, Larsson DJ, Amézquita A, Collignon P, Brandt KK, Graham D W \& Topp E (2013). Management options for reducing the release of antibiotics and antibiotic resistance genes to the environment. Environmental Health Perspectives, 121(8): 878-885.

Salyers AA, Gupta A \& Wang Y. (2004). Human intestinal bacteria as reservoirs for antibiotic resistance genes. Trends in Microbiology, 12(9), 412-416.

Schmitt H, ter Laak T \& Duis K (2017). Development and Dissemination of Antibiotic Resistance in the Environment under Environmentally Relevant Concentrations of Antibiotics and Its Risk Assessment: Journal of AOAC International, 104(2): 154-161.

Sozmen F, Uysal B, Oksal BS, Kose EO \& Deniz IG (2011). Chemical composition and antibacterial activity of Origanum saccatum PH Davis essential oil obtained by solventfree microwave extraction: Comparison with hydrodistillation. Journal of AOAC International, 94(1): 243-250.

Tacão M, Correia A \& Henriques I (2012). Resistance to broad-spectrum antibiotics in aquatic systems: anthropogenic activities modulate the dissemination of bla CTX-M-like genes. Applied and Environmental Microbiology, 78(12): 4134-4140.

Tenaillon O, Skurnik D, Picard B \& Denamur E (2010). The population genetics of commensal 
Escherichia coli. Nature Reviews

Microbiology, 8(3): 207-17.

Tilley E, Ulrich L, Lüthi C, Reymond Ph \& Zurbrügg C (2014). Compendium of Sanitation Systems and Technologies - (Second Revised ed.). Swiss Federal Institute of Aquatic Science and Technology (Eawag), Duebendorf, Switzerland. p. 175.

Titilawo Y, Obi L \& Okoh A (2015). Antimicrobial resistance determinants of Escherichia coli isolates recovered from some rivers in Osun State, South-Western Nigeria: Implications for public health. Science of the Total Environment, doi.10.1016/j.scitotenv.2015.03.095.

United States Environmental Protection Agency. Terms of Environment. 2006-10-03. Retrieved 17-12-2020

Vanderlene LK, Egon AO \& Alan RH (2010). The Accessory Genome of Pseudomonas aeruginosa. Microbiology and Molecular Biology Review, 74(4): 621-641.

Vithanage NR, Yeager TR, Jadhav SR, Palombo EA \& Datta N (2014). Comparison of identification systems for psychrotrophic bacteria isolated from raw bovine milk. International Journal of Food Microbiology, doi.10.1016/j.ijfoodmicro.2014.07.023.

Wackett L (2015). Horizontal gene transfer in environmental microbes. Environmental Microbiology Reports, 7(5): 810-811.

WHO (2006). World Health Organization Guidelines for the safe use of wastewater, excreta, and grey water.World Health Organization. Pp 31.

Ahmadu Bello University, A reflection of our achievement. Department of University Advancement. www.dua.abu.edu.ng 2020. retrieved 27-01-2021.

Zlatanović L, Van Der Hoek JP \& Vreeburg JHG (2017). An experimental study on the influence of water stagnation and temperature change on water quality in a full-scale domestic drinking water system. Water Research, doi.10.1016/j.watres.2017.07.019. 